\title{
TAYLOR RULE AND EMU - MONETARY POLICY DETERMINATION AND ECB'S PREFERENCES ${ }^{1}$
}

\author{
S. Kapounek, L. Lacina \\ Received: June 28, 2006
}

\begin{abstract}
KAPOUNEK, S., LACINA, L.: Taylor rule and EMU - Monetary Policy Determination and ECB's Preferences. Acta univ. agric. et silvic. Mendel. Brun., 2006, LIV, No. 6, pp. 85-96
\end{abstract}

The aim of the article is to evaluate the preferences of the ECB in monetary policy and to compare them with preferences of the central banks of new EU member countries from Central and Eastern Europe. The ECB's responsibility for the primary objective (price stability) often contrasts with the requirement for economic growth stabilization policy from the national governments.

There are doubts if the current members of Eurozone constitute an optimum currency area (the Eurozone 12 is recently the combination of rapidly growing and slow-growing - low inflationary countries). The differences between the countries will even expand during the European monetary union enlargement by new EU member countries. Consequently the probability of asymmetric shocks will increase. The main question is the ability of ECB to fulfill the needs of all EMU member countries in terms of optimal monetary policy. In the first part the authors analyze differences between the preferences of the ECB and national authorities (governments). The negative experiences of Ireland, Italy and other EMU members with current status quo help us to understand fear of future member countries from possible impact of common monetary policy on their national economies.

The second part of the paper deals with interest rates determination by ECB and compares it with expectations (requirements) from EMU member and EMU candidate countries. The main contribution of the article may be seen in central bank's preferences analyses - the preferences are defined as the parameters in Taylor rule (the weights given by ECB and national authorities to the price stability and economic growth stimulation).

The hypothesis is defined as following: are the preferences of ECB in line with the preferences of national central banks of EMU candidate countries?

The empirical analysis is based on the Taylor rule decomposition. The hypothesis is tested by regression analysis. Time series regression model uses relations between the inflation target, potential output, current macroeconomic situation on the one side and current monetary policy strategy, represented by interest rates, on the other side.

A range of empirical studies refers to differences between the desired interest rates of member and future member countries of EMU. The level of desired interest rates changes continuously according to the current economic situation of individual national economies. The differences are given by dissimilarities in financial systems, transmission mechanisms, and historical context of monetary arrangements. The authors suppose that the national authorities' and central banks' preferences are constant in the short time or identical before and after enlargement. The main idea of the article is that the traditional approach, which compares desired interest rates by national central banks, is irrelevant before full membership in EMU. The center of the problem is the mutual agreement on preferences of common monetary

1 It is revised version of the paper, which was presented on 61st International Atlantic Economic Conference, Berlin, /Germany/, 15.-19. March 2006. 
policy. The answer to the question: how to evaluate real impact of common monetary policy on real economy of EMU candidate countries after their entrance to Eurozone, is expected result of the article.

Taylor rule, ECB, monetary integration, inflation targeting, interest rate determination

European central bank (ECB) has defined its primary aim in the Maastricht Treaty in the form of maintaining the price stability. ${ }^{2}$ Reaching the secondary objectives, particularly the stabilization of business cycle and unemployment, cannot threaten the primary objective at the same time. The possibility of credibility loss in case of not fulfilling the primary objective presses the ECB to the role of conservative central bank, which in all circumstances follows the policy of price stability. The maintenance of price stability to the expense of employment and growth however starkly contrasts with preferences of the national authorities of the Eurozone member countries and society as a whole. Inhabitants of the EMU member countries rather accept the arguments for keeping inflation under control, but their preferences are not concentrated on the price stability only. They are much more sensitive to the problem of unemployment. The elected political representatives thus increase the political pressure on the ECB and its independence, given by Maastricht Treaty, can be in consequence threatened in the process (De Grauwe, 2005, pp. 168-176).

A marked difference in preferences can be expected in candidate countries for the EMU membership. It is supposable that thank to their effort to receive a certain level of real convergence these states will show higher growth, accompanied by higher inflation. Their monetary policy is fully in accord and in balance with their macroeconomic situation. Their recent interest rate does not differ much from the rates in Eurozone. The source of asymmetry may be found in different perception of real situation in national economies from the viewpoint of the reaction of ECB monetary policy and of individual national central banks of candidate states in respect to the economic growth and inflation gap. The authors assume, that the preferences of central banks of individual candidate countries as the Czech Republic, Estonia, Cyprus, Latvia, Lithuania, Hungary, Malta, Poland, Slovenia a Slova- kia, should not differ from the ECB preferences. The potential differences could lead to significant increase in frequency of critics and presses on ECB compared to current status quo, because the common monetary policy would not reflect the preferences of these states.

The theoretical interpretation of different effect of ECB preferences and the Eurozone inhabitants depicted De Grauwe (2004) via Barro-Gordon model. The practical quantification is provided by monetary instrument rules. The relation between the central bank monetary policy, represented by the reference interest rate level, inflation and growth was defined in 1993 by the Stanford University economist, John Taylor (1993):

$i_{t}=r^{*}+\pi^{T}+a\left(\pi_{t}-\pi^{T}\right)+b x_{t}$,

where $\mathrm{i}_{\mathrm{t}}$ represents desired value for the central bank's policy instrument, $r^{*}$ is equilibrium long-term real interest rate, $\pi^{\mathrm{T}}$ the constant level of central bank inflation target, $\pi_{t}$ actual inflation (measured by the GDP deflator) and $\mathrm{x}_{\mathrm{t}}$ production gap. The parameters $a, b$ represent the weights (preferences), which is by central bank attributed to the economic objectives (growth and price stability). So they represent its preferences in the choice between the growth stimulation on the one hand and inflation reduction on the other hand.

Taylor rule is an elegant tool for the central banks behavior description, coming out from reactions to inflation and the growth deviations from its desired, target levels. Central bank raises the interest rates over the equilibrium level in case, if the inflation grows over its inflation target (or in case of the cyclic growth, if the inflation growth exceeds the trend). The weights (parameters $a, b$ ) inflation and growth gap specify the type of central bank. If $b=0$, it can be spoken about very conservative central bank, which follows only the inflation target, not the economic growth. Begg, D. et al. (2002) analyzed the parameters, the weights given to inflation and growth gap by

2 ,The primary objective of the ESCB shall be to maintain price stability. Without prejudice to the objective of price stability, the ESCB shall support the general economic policies in the Community with a view to contributing to the achievement of the objectives of the Community as laid down in article 2"(The Treaty, Article 105). Article 2 describes secondary objectives as ,harmonious, balanced and sustainable development of economic activities, a high level of employment and of social protection, equality between men and women, sustainable and non-inflationary growth, a high degree of competitiveness and convergence of economic performance, a high level of protection and improvement of the quality of the environment, the raising of the standard of living and quality of life, and economic and social cohesion and solidarity among Member States. “ 
ECB in amount $\mathrm{a}=2,0 \mathrm{a} \mathrm{b}=0,8 .^{3}$ According to these data the ECB can be characterized as a bank, which concentrates both on the inflation and on the economic growth, however preferring the inflation target.

The aim of this article is to make an empirical analysis of ECB preferences and central banks of candidate countries for EMU membership. The preferences are defined as the parameters in Taylor rule (the weights given by ECB and national authorities to the price stability and economic growth stimulation). The hypothesis is defined as following: are the preferences of ECB in line with the preferences of national central banks of EMU candidate countries?

\section{MATERIAL AND METHODS}

The robustness of empirical derivation of the Taylor's rule is directly dependent on the choice of suitable preliminary data and their adjustments. Considering the equilibrium between the reference interest rates of the central banks and the macroeconomic development of economy just in actual time $t$ doesn't correspond to real conditions. The reference interest rates level can show the gap towards basic macroeconomic variables. The reason is not only the reaction ability of central bank, but also the accessibility of the data published by statistical offices. Walsh (2003) interprets the lag as the inertial behavior that would arise under an optimal pre-commitment policy. "It has also been interpreted to mean that central banks adjust gradually toward a desired interest-rate level. For example, suppose that $i^{*}$ is the central bank's desired value for its policy instrument. Suppose, however, that it wants to avoid large changes in interest rates. Such an interest-smoothing objective might arise from a desire for financial market stability. If the central bank adjusts $i_{t}$ gradually toward $i^{*}{ }^{*}$, then the behavior of $i_{t}$ may be captured by a partial adjustment model of the form:

$i_{t}=i_{t-1}+\theta\left(i^{*}{ }_{t}-i_{t-1}\right)=(1-\theta) i_{t-1}+\theta i^{*}{ }_{t}$.

The estimated coefficient on $i_{t-1}$ provides an estimates of $1-\theta$. Values close to 1 imply that $\theta$ is small; each period the central bank closes only a small fraction of the gap between its policy rate and its desired value." (Walsh, 2003, pp. 547). Thus if there was considered in the analysis the reference interest rates of central banks, there would have been used the time series smoothing by including a lagged interest rate term (Rudebusch, 2002).

The next potential lag can be identified between the increase/decrease of monetary base and inflation. „The lag between money aggregates and inflation was in EU member states before the eurozone formation estimated for 6 to 9 months. " (Jílek, J., 2004, pp. 422 , translated by the author).

The authors suppose that the robustness of the analysis would be increased, if the central bank reference rate will be replaced by short-term interest rate of the interbank market. ${ }^{4}$ The lag between monetary policy and its impact on the financial sector thus will be excluded and the analysis will use the market interest rate, which is reflecting better the actual economic situation.

The next problem arises by setting the equilibrium long-term real interest rate. Taylor (1993) has estimated its level on the fixed level $2 \%$ in the conditions of the USA economy. The conditions not only in the Eurozone, but particularly in candidate states vary from the conditions of the US economy. As we already mentioned the process of real convergence of candidate countries is accompanied by higher growth and inflation. That's why we replaced in the original relation (1) the variable $r^{*}$, the equilibrium long-term real interest rate by the long-term risk-free interest rate. In the regression model is the risk-free interest rate replaced with the constant:

$I_{t}=c+a\left(\pi_{t}-\pi^{T}\right)+b x_{t}$,

where $i_{t}$ represents short-term interbank interest rate. In the analyzed observed period inflation targets were changed by individual central banks not only considering their levels, but also considering their own form and interpretation. ${ }^{5}$ That is why the authors for the reason of comparability of the results in this article chose the constant inflation target level in form of HICP year-to-year growth amounting to $2 \%$ (Taylor, 1993). $2 \%$ inflation target is fully consistent with the ECB primary objective $(\mathrm{ECB}, 2002)$ and also with Maastricht criterions of the price stability for the integration of candidate countries in EMU. The problems of using the constant inflation target and constant equilibrium real rate from a view of various authors and empirical studies are summarized by Siklos and Wohar (2005).

3 Considering the modification of the relation to the form, where the sum of parameters equal 1, it would be necessary to divide the whole equation by the sum of parameters $\boldsymbol{a}$ and $\boldsymbol{b}$. The empirical analysis used in this article abstracts away from this condition.

4 Day-to-day money market interest rates: averages for the euro-zone (EONIA = Euro Overnight Index Average), and national series.

5 E.g. Czech national bank used net inflation targets since December 1997 and targeting of retail prices since April 2001. Hungarian central bank has officially launched the inflation targeting since June 2001. 
The actual inflation is then considering the inflation target of quarterly value of year-to-year change represented by Harmonized Index of Consumer Prices (HICP).

The determination of production gap is dependent on the potential product estimation. The approximation can be accomplished by two ways. With the help of the econometric model, based on the production function or on the assessment of potential product with GDP smoothing, the long-term trend is estimated. The production gap is then defined as the difference of the real GDP and the GDP trend (Hájek, M, Bezděk, V, 2000):

$x_{t}=y_{t}-y_{t}^{*}$,

where $y_{t}$ represents GDP in stable prices and $y_{t}^{*}$ its potential, trend level. In the article authors used the second method, the identification of the long-term trend in time series (e.g. Woodford, 2001). Own determination of long term in time series is usually identified via filter techniques. Canova (1999) using for identification of the trend and the cyclic component in economic cycle with the Kalman filter, Hodrick-Prescott filter and band-pass filter. Authors Hodrick and Prescott themselves (1980) recommend the utilization of filter techniques for the identification of the longterm trend in the business cycle. Fidrmuc and Korhonen (2004) summarize 27 different filter techniques from various authors during in period 1998-2004 for the time series analysis, particularly the business cycles. The subjectivity in the choice of the suitable filter and its parameters is the main reason of distorting the results. This imperfection is removed in BoxJenkins (B-J) methodology, allowing the modeling of time series with the help of mixed autoregressive process of order $p$, process of the moving averages of order $q$ and with the differencials of order $d$ (Arlt and Arltová, 2003 and 1997). In the process ARIMA(p, $\mathrm{d}, \mathrm{q})$, represents free parameter and $x_{t}$ gauss ${ }^{6}$ white noise:

$Y_{t}=\theta+\alpha_{1} Y_{t-1}+\beta_{0} x_{t}+\beta_{1} x_{t-1}$.

In the comparison with the filter techniques B-J methodology looks rather simpler. It is linear model based on the identification of the systematic component with the help of autocorrelation, but its identification has firmly standardized order. The model parameters are determined by means of the form of correlogram of residues. The value of autocorrelative and partial autocorrelative function of residues must be found in the tolerance limits for rejecting the hypothesis of correlation of the residues is tested on the $5 \%$ significance level. The contribution of the test is thus the reduction of the subjectivity.

The analysis is done only for the time period of ECB functioning, so the period of years 1998-2005. It rather gets to reduction of number of observation, however the preferences in case of Eurozone apply only to ECB and do not include the behavior of the other bank, for example Bundesbank (ČSOB, 2004). Also some distorting coming from the different preferences of central banks of candidate countries in transformational period of the first half of nineties were replaced. For the reason of the accessibility of comparable data the Eurozone comes to the empirical analysis as the whole, and then 3 individual candidate countries for membership in EMU - the Czech Republic, Hungary and Poland. The values of quarterly year-to-year change of GDP in Poland's case are not available only since second quarter 2005 . The quarterly values thus provides in total 20 observations. This number can be considered to be sufficient for the regression analysis.

Taylor's rule expresses the steady state, which of course is not the condition in the real economy. Ramon (2005) identifies in his analysis the relation, approaching the equilibrium in the Czech Republic, Poland, Hungary and in case of Eurozone.

\section{RESULTS}

Tab. I-VI present the results of multiple regression analysis. The relation (3) is apparent on 5\% significance level in Poland, the Czech Republic and Hungary. The relation is apparent on $10 \%$ significance level in Eurozone. In case of Slovakia and Malta there was not found any statistically important relation between the variables so we can not estimate the parameters $a$ and $b$. Eurozone, the Czech Republic and Poland then congruently prove the dependence of short-term interest rates on the inflation gap. The relation between the level of interest rates and the growth gap was not proved. We can therefore say, that ECB, central bank of Poland and Czech National Bank prefer in their decision-making the actual inflation, over the economic growth. The influence of economic growth on monetary policy of these central banks is disputable. In the case of ECB and the central bank of the Czech Republic there was even the negative parameter $b$ analyzed. Parameter $b$ is further not considered, because it was not identified at statistically significant level in the analysis.

In case of Hungary both of the parameters are statistically significant. The relation (3) for Hungary can be written as follows:

$i_{t}=7,73+0,48\left(\pi_{t}-2\right)+0,96\left(x_{t}\right)$.

The Hungarian central bank thus visibly preferred the growth stimulation to price level stability during the whole period 2000-2005.

If we abstract from the small statistical significance of dependence of parameter $b$ on the level of shortterm interest rate, the relation (3) for Eurozone (7), the Czech Republic (8) and Poland (9) can be expressed as follows: 
$i_{t}=2,71+1,76\left(\pi_{t}-2\right)+0,30\left(x_{t}\right)$

$i_{t}=3,28+0,46\left(\pi_{t}-2\right)-0,75\left(x_{t}\right)$

$i_{t}=7,48+1,59\left(\pi_{t}-2\right)-0,51\left(x_{t}\right)$.

\section{DISCUSSION}

The significant level of parameter $a$, which is identifying the preferences of the central bank in connection with its inflation target was analyzed at ECB, Czech National Bank (CNB) and Poland central bank. So in case of ECB we can fully confirm the fact, that the bank really prefers its primary objective, which is the price stability. The results are not surprising also in the case of the Czech Republic. CNB is in the long term unsuccessful in holding the inflation within the bands of inflation target. In some years the value of real inflation markedly undershot the lower band of inflation target, and in the year 2004 the rate of inflation even reached the negative numbers. CNB is also criticized by an array of economist (e.g. Janáček, 1999, Klaus, 2000 or Žídek, 2006) for its too restrictive policy selected in the period after currency crisis in the year 1997. CNB absolutely univocally preferred the aim of price stability at the expense of economic growth stimulation, which according to the above mentioned authors extended the period of economic depression after the currency crisis. The tax for the price stability (Tab. VII) was considerable deceleration of the economic growth in the period of years 1998 - 1999 and again in the year 2002. The effort of the polish central bank to lower the double- digit inflation value in the year 2000 had a similar effect on the economic growth. The growth going over $4 \%$ decreased to about 1\% (Tab. VII) in the years 2001 and 2002.

After the entrance of these two candidate countries (the Czech Republic and Poland) to Eurozone we can expect the consistent preferences of ECB with current central banks even if the conditions in these states will change. On the contrary the Hungarian central bank prefers the growth stimulation to the stabile price level. After the entrance of Hungary to Eurozone a conflict between the ECB preferences and the Hungarian central bank representative in the Council of ECB can arise.

The preference analysis of central banks of Malta and Slovakia did not prove any statistically significant causality between the short-term interest rate inter banks, the inflation gap and the growth gap. On that account the authors suppose, that in these two economics the balance of monetary policy and the macroeconomic progress is disturbed. In Slovakia's case this conclusion is fully consistent with Ramon (2005).

Nevertheless we can expect the conflict of claims to setting of ECB's monetary policy in all the candidate states, because they will not reach, according to the empirical studies focused on the convergence of price levels (e.g. Ševela, 2005), the full price convergence until their expected entrance the Eurozone (20082011). A certain restriction will be also the differences in real convergence in the period of fixing of currency rate by the entrance to ERM2 system. Thereby those economies lose one of the channels of price and real convergence that is the appreciation of the rate of exchange. The real convergence of the candidate countries will be then possible only via faster economic growth and eventually via higher dynamics of inflation. And here we are back to the conflict in preferences between Irish economy and ECB monetary policy, which was mentioned at the beginning of the article (fast growth, overheated economy), respectively Italy (slow economic growth and complains on too restrictive approach of ECB).

Tab. VII presents quarterly indicators of harmonized index of the consumer prices and the growth of GDP in constant prices.

Due to data incomparability, particularly the inflation target of individual central banks, it does not allow the comparability of the identified parameters values with other studies. The authors perpetrated certain distorting while identifying production gap. The length of time series gives the robustness of potential product analysis. The reliability of analysis requires at least two complete business cycles. Number of observations does not fulfill this precondition.

The interesting thing is the comparison of the economic growth of Eurozone and USA. The Federal Reserve System represents here the central bank with several targets (objectives). Taylor (1993) has estimated the weights between the inflation and growth gap identically on 0,5 . The empirical analysis accomplished in this article proves that ECB is a typical conservative bank with just one, dominant primary objective. As we could expect, the economic growth of USA should be faster than in Eurozone. The data in Tab. VIII confirm this assumption. 
I: Multiple Regression Analysis - Eurozone

\begin{tabular}{|c|c|c|c|c|}
\hline & & Standard & $\mathrm{T}$ & \\
\hline Parameter & Estimate & Error & Statistic & P-Value \\
\hline CONSTANT & 2,71071 & 0,290224 & 9,34008 & 0,0000 \\
\hline $\mathrm{a}$ & 1,76172 & 0,968615 & 1,8188 & 0,0866 \\
\hline b & $-0,296115$ & 0,341705 & $-0,866582$ & 0,3982 \\
\hline
\end{tabular}

\begin{tabular}{|c|c|c|c|c|c|}
\hline \multicolumn{6}{|c|}{ Analysis of Variance } \\
\hline Source & Sum of Squares & Df & Mean Square & F-Ratio & P-Value \\
\hline Model & 5,60146 & 2 & 2,80073 & 2,95 & 0,0792 \\
\hline Residual & 16,1152 & 17 & 0,947953 & & \\
\hline
\end{tabular}

Source: Own calculation, software Statgraphics 3.1

II: Multiple Regression Analysis - Czech Republic

\begin{tabular}{|c|c|c|c|c|}
\hline & & Standard & $\mathrm{T}$ & \\
\hline Parameter & Estimate & Error & Statistic & P-Value \\
\hline CONSTANT & 3,27753 & 0,202081 & 16,2189 & 0,0000 \\
\hline $\mathrm{a}$ & 0,455632 & 0,12705 & 3,58623 & 0,0023 \\
\hline $\mathrm{b}$ & $-0,745398$ & 0,562352 & $-1,3255$ & 0,2025 \\
\hline
\end{tabular}

\begin{tabular}{|c|c|c|c|c|c|}
\hline \multicolumn{6}{|c|}{ Analysis of Variance } \\
\hline Source & Sum of Squares & Df & Mean Square & F-Ratio & P-Value \\
\hline Model & 20,72 & 2 & 10,36 & 14,08 & 0,0002 \\
\hline Residual & 12,5051 & 17 & 0,735593 & & \\
\hline
\end{tabular}

Source: Own calculation, software Statgraphics 3.1

III: Multiple Regression Analysis - Poland

Dependent variable: $\mathrm{i}(\mathrm{t})$

\begin{tabular}{|c|c|c|c|c|}
\hline & & Standard & $\mathrm{T}$ & \\
\hline Parameter & Estimate & Error & Statistic & P-Value \\
\hline CONSTANT & 7,47825 & 0,935543 & 7,99349 & 0,0000 \\
\hline $\mathrm{a}$ & 1,58928 & 0,311691 & 5,0989 & 0,0001 \\
\hline $\mathrm{b}$ & 0,506851 & 0,623214 & 0,813286 & 0,4273 \\
\hline
\end{tabular}

Analysis of Variance

\begin{tabular}{|c|c|c|c|c|c|}
\hline Source & Sum of Squares & Df & Mean Square & F-Ratio & P-Value \\
\hline Model & 354,433 & 2 & 177,216 & 14,43 & 0,0002 \\
\hline Residual & 208,715 & 17 & 12,2774 & & \\
\hline
\end{tabular}

Source: Own calculation, software Statgraphics 3.1 
IV: Multiple Regression Analysis - Hungary

\begin{tabular}{|c|c|c|c|c|}
\hline & & Standard & $\mathrm{T}$ & \\
\hline Parameter & Estimate & Error & Statistic & P-Value \\
\hline CONSTANT & 7,73289 & 0,614395 & 12,5862 & 0,0000 \\
\hline $\mathrm{a}$ & 0,485988 & 0,119117 & 4,07993 & 0,0008 \\
\hline $\mathrm{b}$ & 0,963736 & 0,516435 & 1,86613 & 0,0794 \\
\hline
\end{tabular}

\begin{tabular}{|c|c|c|c|c|c|}
\hline \multicolumn{6}{|c|}{ Analysis of Variance } \\
\hline Source & Sum of Squares & Df & Mean Square & F-Ratio & P-Value \\
\hline Model & 30,4967 & 2 & 15,2484 & 10,40 & 0,0011 \\
\hline Residual & 24,916 & 17 & 1,46565 & & \\
\hline
\end{tabular}

Source: Own calculation, software Statgraphics 3.1

V: Multiple Regression Analysis - Slovak Republic

\begin{tabular}{|c|c|c|c|c|}
\hline & & Standard & $\mathrm{T}$ & \\
\hline Parameter & Estimate & Error & Statistic & P-Value \\
\hline CONSTANT & 5,26703 & 0,820689 & 6,41782 & 0,0000 \\
\hline $\mathrm{a}$ & 0,145969 & 0,163175 & 0,894556 & 0,3835 \\
\hline $\mathrm{b}$ & 0,413779 & 0,552044 & 0,74954 & 0,4638 \\
\hline
\end{tabular}

\begin{tabular}{|c|c|c|c|c|c|}
\hline \multicolumn{6}{|c|}{ Analysis of Variance } \\
\hline Source & Sum of Squares & Df & Mean Square & F-Ratio & P-Value \\
\hline Model & 4,09522 & 2 & 2,04761 & 0,74 & 0,4902 \\
\hline Residual & 46,8091 & 17 & 2,75348 & & \\
\hline
\end{tabular}

Source: Own calculation, software Statgraphics 3.1

VI: Multiple Regression Analysis - Malta

\begin{tabular}{|c|c|c|c|c|}
\hline & & Standard & $\mathrm{T}$ & \\
\hline Parameter & Estimate & Error & Statistic & P-Value \\
\hline CONSTANT & 3,61629 & 0,20048 & 18,0381 & 0,0000 \\
\hline $\mathrm{a}$ & 0,165621 & 0,275512 & 0,60114 & 0,5557 \\
\hline $\mathrm{b}$ & $-0,0634393$ & 0,0624946 & $-1,01512$ & 0,3243 \\
\hline
\end{tabular}

Analysis of Variance

\begin{tabular}{|c|c|c|c|c|c|}
\hline Source & Sum of Squares & Df & Mean Square & F-Ratio & P-Value \\
\hline Model & 0,56148 & 2 & 0,28074 & 0,58 & 0,5703 \\
\hline Residual & 8,2203 & 17 & 0,483547 & & \\
\hline
\end{tabular}

Source: Own calculation, software Statgraphics 3.1 
VII: Inflation and GDP in selected countries

\begin{tabular}{|c|c|c|c|c|c|c|}
\hline \multirow[b]{2}{*}{ Time period } & \multicolumn{2}{|c|}{ Czech Republic } & \multicolumn{2}{|c|}{ Poland } & \multicolumn{2}{|c|}{ Hungary } \\
\hline & $\begin{array}{l}\text { GDP in } \\
\text { constant } \\
\text { prices }\end{array}$ & $\begin{array}{l}\text { Inflation } \\
\text { (HICP) }\end{array}$ & $\begin{array}{l}\text { GDP in } \\
\text { constant } \\
\text { prices }\end{array}$ & $\begin{array}{l}\text { Inflation } \\
\text { (HICP) }\end{array}$ & $\begin{array}{l}\text { GDP in } \\
\text { constant } \\
\text { prices }\end{array}$ & $\begin{array}{c}\text { Inflation } \\
\text { (HICP) }\end{array}$ \\
\hline $1998 q 01$ & $-2,00$ & 12,27 & 5,90 & 13,93 & 4,40 & 17,20 \\
\hline $1998 \mathrm{q02}$ & $-1,40$ & 11,63 & 4,50 & 13,03 & 4,90 & 15,57 \\
\hline $1998 \mathrm{q} 03$ & $-0,80$ & 8,67 & 5,40 & 11,17 & 5,40 & 13,33 \\
\hline $1998 \mathrm{q} 04$ & $-0,40$ & 6,50 & 3,60 & 9,30 & 4,70 & 11,10 \\
\hline 1999q01 & 0,10 & 2,50 & 1,40 & 6,10 & 3,20 & 9,37 \\
\hline $1999 q 02$ & 0,90 & 1,93 & 3,50 & 6,33 & 3,30 & 8,93 \\
\hline $1999 q 03$ & 1,70 & 0,97 & 4,20 & 7,03 & 4,20 & 10,67 \\
\hline $1999 q 04$ & 2,10 & 1,87 & 6,90 & 9,17 & 5,90 & 10,93 \\
\hline 2000q01 & 3,30 & 3,57 & 6,50 & 10,33 & 7,50 & 10,00 \\
\hline $2000 q 02$ & 4,00 & 3,70 & 4,90 & 10,07 & 6,50 & 9,33 \\
\hline $2000 q 03$ & 4,10 & 4,17 & 2,20 & 10,83 & 5,30 & 10,07 \\
\hline $2000 q 04$ & 4,10 & 4,30 & 2,60 & 9,17 & 4,90 & 10,40 \\
\hline $2001 q 01$ & 3,40 & 4,07 & 2,10 & 6,70 & 4,60 & 10,20 \\
\hline 2001q02 & 2,90 & 5,03 & 0,60 & 6,63 & 4,60 & 10,50 \\
\hline $2001 q 03$ & 2,40 & 5,07 & 1,30 & 4,53 & 4,40 & 8,67 \\
\hline $2001 q 04$ & 1,90 & 4,03 & 0,30 & 3,57 & 3,80 & 7,13 \\
\hline $2002 q 01$ & 1,90 & 3,37 & 0,70 & 3,50 & 3,50 & 6,23 \\
\hline $2002 q 02$ & 1,60 & 1,97 & 1,60 & 1,90 & 3,50 & 5,43 \\
\hline $2002 q 03$ & 1,20 & 0,27 & 1,70 & 1,37 & 4,00 & 4,50 \\
\hline $2002 q 04$ & 1,20 & 0,17 & 1,50 & 1,00 & 4,20 & 4,87 \\
\hline $2003 q 01$ & 2,40 & $-0,63$ & 2,60 & 0,40 & 3,20 & 4,73 \\
\hline $2003 q 02$ & 3,10 & $-0,23$ & 4,60 & 0,33 & 3,00 & 3,93 \\
\hline $2003 q 03$ & 3,60 & $-0,17$ & 3,80 & 0,67 & 3,30 & 4,67 \\
\hline $2003 q 04$ & 3,60 & 0,80 & 4,20 & 1,37 & 4,10 & 5,33 \\
\hline 2004q01 & 4,00 & 2,03 & 7,60 & 1,80 & 4,90 & 6,77 \\
\hline $2004 q 02$ & 4,80 & 2,43 & 6,30 & 3,37 & 4,90 & 7,43 \\
\hline $2004 q 03$ & 4,90 & 3,03 & 4,50 & 4,77 & 4,30 & 7,03 \\
\hline $2004 q 04$ & 5,00 & 2,73 & 3,70 & 4,50 & 4,50 & 5,87 \\
\hline $2005 \mathrm{q} 01$ & 5,00 & 1,37 & 3,80 & 3,63 & 3,20 & 3,53 \\
\hline $2005 q 02$ & 5,20 & 1,20 & 1,00 & 2,23 & 4,50 & 3,67 \\
\hline $2005 q 03$ & 4,90 & 1,60 & $:$ & 1,73 & 4,50 & 3,57 \\
\hline
\end{tabular}

Data source: Eurostat, adjusted by the authors 
VIII: GDP growth in constant prices in Eurozone and USA (1993-2004)

\begin{tabular}{|c|c|c|}
\hline & Eurozone & USA \\
\hline 1993 & $-0,4$ & 2,7 \\
\hline 1994 & 2,8 & 4,0 \\
\hline 1995 & 2,4 & 2,5 \\
\hline 1996 & 1,6 & 3,7 \\
\hline 1997 & 2,5 & 4,5 \\
\hline 1998 & 2,9 & 4,2 \\
\hline 1999 & 2,9 & 4,4 \\
\hline 2000 & 3,6 & 3,7 \\
\hline 2001 & 1,7 & 0,8 \\
\hline 2002 & 1,0 & 1,9 \\
\hline 2003 & 0,8 & 3,0 \\
\hline 2004 & 2,3 & 4,4 \\
\hline $1993-2004$ & 2,01 & 3,32 \\
\hline
\end{tabular}

Data Source: Eurostat

\section{SUMMARY}

The main contribution of the article to the discussion about the consonance of preferences of ECB and national central banks of candidate countries for membership in EMU lies in the non-traditional estimation of Taylor's rule. The empirical analysis comes here from short-term market interest rates on interbank market as from exogenous values. The studies of other discussed authors consider the short-term interest rates to be endogenous values, representing the desired interest rates level for given economies. The authors of this article do not compare requested interest rates levels on the basis of accessible data, but they compare own preferences of central banks, expressed by parameters $a$ and $b$. This procedure is more suitable considering the difference of the conditions for growth and inflation in candidate countries and in Eurozone, so to different levels of requested interest rates. Even in the case of the same preferences of individual central banks this approach looks more suitable. The conditions for the growth and relating inflation pressures can in candidate countries after their entrance thanks to real convergence process significantly change. The change of the preferences of the representatives of their central banks cannot be expected.

The empirical analysis proved that the Hungarian central bank visibly prefers the growth stimulation over price level stability. The ECB, Czech National Bank and National Bank of Poland prefer price level stability during the analyzed period.

\section{SOUHRN}

Taylorovo pravidlo a HMU - stanovení preferencí monetární politiky ECB

Primárním cílem ECB, definovaným v Maastrichtských kritériích, je udržení stabilní cenové hladiny. V př́padě, že je tento cíl splněn, může tato centrální banka svou monetární politiku zaměřit na stimulaci růstu a zaměstnanosti v HMU. Obavy z nesplnění primárního cíle s důsledkem ztráty kredibility staví ECB do role velmi konzervativní banky. Její konzervativní přístup je kritizován nejen ze stran kandidátských zemí na vstup do HMU, které mají v porovnání s HMU tendence dosahovat vyššího růstu za cenu vyššího růstu cenové hladiny, ale také ze stran stávajících členských států HMU. Odlišné požadavky na expanzivnost či restriktivnost monetární politiky ECB se vyskytují z důvodu rozdílných temp růstu a inflace v jednotlivých státech Eurozóny. Elegantním nástrojem pro výpočet požadované výše úrokové sazby na základě mezery růstu a inflační mezery, tedy odchylky inflace od cílové hodnoty, je Taylorovo pravidlo.

Hlavním přínosem článku je diskuse na téma konzistentnosti preferencí ECB a národních centrálních bank kandidátských zemí na vstup do EMU, založená na netradičním empirickém odhadu parametrů Taylorova pravidla. Do empirické analýzy vstupují jako exogenní proměnné krátkodobé úrokové sazby 
na mezibankovním trhu. Soudobé empirické studie považují krátkodobé úrokové sazby na mezibankovním trhu za endogenní proměnné, reprezentující požadovanou výši úrokových sazeb v podmínkách jednotlivých států. Cílem autorů tohoto článku není porovnat požadovanou výši krátkodobých úrokových sazeb, ale analyzovat vlastní preference centrálních bank. Tyto jsou v modelu vyjádřeny parametry $a$ a $b$. Rozdíly mezi jednotlivými státy v podobě rozdílných temp růstu a inflace se sice odrážejí v různých úrovních požadovaných úrokových sazeb, ale za mnohem vhodnější autoři považují rozdíly v preferencích centrálních bank těchto zemí. Po začlenění kandidátských zemí do EMU lze díky procesu reálné konvergence očekávat změnu inflačních tlaků i podmínek růstu. Změnu v preferencích monetárních autorit daných zemí ale očekávat nelze.

Empirická analýza prokázala, že Centrální banka Mad’arska viditelně preferuje stimulaci růstu před stabilitou cenové hladiny. V analyzovaném období ECB, Česká národní banka a Národní banka Polska shodně preferují stabilitu cenové hladiny před stimulací ekonomického růstu (tab. I-VI).

Talorovo pravidlo, ECB, měnová integrace, cílování inflace, determinace úrokové sazby

\section{JEL CATEGORY}

\section{E42 Monetary Integration or E50 Money Supply/policy}

We thank to prof. Rusek (Dept. of Economics, Susquehanna University, Selinsgrove, PA 17870, USA) and Jitka Poměnková, Ph.D. (Dept. of Statistics and Operational Analysis, Faculty of Business and Economics, Mendel University of Agriculture and Forestry Brno) for the useful comments to the first drafts of the paper. All remaining errors are our owns.

The results introduced in the article are outcomes of the research intent n. MSM 6215648904 with the title"The Czech Economy in the Process of Integration and Globalization, and the Development of Agricultural Sector and the Sector of Services under the New Conditions of the Integrated European Market", thematic area "Macroeconomic and microeconomic performance of the Czech economy, and the Czech government's economical-political measures in the context of the integrated European market." The holder of the research intent is Mendel University of Agriculture and Forestry Brno, Faculty of Business and Economics.

\section{REFERENCES}

ARLT, J.: Moderní metody modelování ekonomických časových řad. Praha: Grada Publishing, 1999, pp. 15-17. ISBN: 80-7169-539-4.

ARLT, J., ARLTOVÁ, M.: Příklady z analýzy ekonomických časových řad. Praha: VŠE v Praze, 1997, pp. 91-129. ISBN 80-7079-056-3.

ARLT J., ARLTOVÁ, M.: Finanční časové rady vlastnosti, metody modelování, př́klady a aplikace. Praha: Grada Publishing, 2003, pp. 29-62. ISBN 80 247-0330-0.

BEGG, D., CANOVA, F., De GRAUWE, P., FATÁS, A., LANE, P.: Surviving the slowdown. Monitoring the European Central Bank. London: Centre for Economic Policy Research, 2002. ISBN: 1-89812865-0.

CANOVA, F.: Does detrending matter for the determination of the reference cycle and the selection of turning points. [online] 2004 [cit 2006-02-01] $<$ http://ideas.repec.org/p/upf/upfgen/113.html>

ČSOB, a. s.: Ekonomický měsićník. Záři 2004. [online] 2004 [cit 2006-03-02] <http://www.csob.cz/ data/ft/bulletin/BC_0409.pdf>

De GRAUWE, P.: Economics of Monetary Union.
Sixth Edition Oxford: Oxford University Press, 2005. ISBN 0-19-927700-1.

EUROPEAN CENTRAL BANK: The Single Monetary Policy in the Euro Area: General documentation on Eurosystem monetary policy instruments and procedures. April 2002 Frankfurt am Main: European Central Bank, 2002. ISBN: 92-9181-265-X.

FIDRMUC, J., KORHOEN, L.: A meta-analysis of business cycle correlation between the euro area and CEECs: What do we know - and who cares? Discussion Papers, No. 20. Bank of Finland, BOFIT - Institute for Economies and Transition. Helsinki, December 2004. ISBN: 951-686-982-3.

HÁJEK, M., BEZDĚK, V.: Odhad potenciálního produktu a produkčni mezery v $\check{C} R$ [online] 2000 [cit. 2006-01-06] <www.cnb.cz/www.cnb.cz/en/ research/research_publications/mp_wp/download/ vp26hajekbezdek.pdf>

HODRICK, R.J., PRESCOTT, E.C.: Postwar U.S. business cycles: An Empirical Investigation. [online] 1997 [cit. 2005-08-07] <http://ideas.repec.org/ a/mcb/jmoncb/v29y1997i1p1-16.html>

JANÁČEK, K., ČIHÁK, M. FRÝDMANOVÁ, M., HOLUB, T. ZAMRAZILOVÁ, E.: Czech Economy in Year 1999: A Knotty Way to Economic Recove- 
ry. Prague: Political Economy, 1999, No. 2, ISSN: 0032-3233.

JÍLEK, J.: Penize a ménová politika. Praha: Grada Publishing, 2004. ISBN 80-247-0769-1.

RAMON, M. D.: Monetary Policy Rules In Accession Countries to EU: Is the Taylor rule a pattern? [online] 2005 [cit. 2006-01-10] <http://economicsbulletin.vanderbilt.edu/2005/volume5/EB-04E50013A. pdf $>$

RUDEBUSCH, G. D.: Is the Fed too Timid? Monetary Policy in an Uncertain World. Review of Economics and Statistics 83(2): 203-17, ISSN: 00346535.

RUDEBUSCH, G. D.: Term Structure Evidence on Interest Rate Smoothing and Monetary Policy Inertia. Journal of Monetary Economics 49: 1161-1187, ISSN: 0304-3932.

SIKLOS, P. L., WOHAR, M. E.: Estimating TaylorType Rules: An Unbalanced regression? [online]
2004 [cit. 2006-014-15] <http://www.bus.lsu.edu/ economics/faculty/chill/personal/aie/siklos.pdf>

STÉCLEBOUT, E.: Monetary Policy-Making in an Enlarging European Union. [online] 2004 [cit. 2006-01-15]

http://www.univ-orleans.fr/deg/GDRecomofi/Activ/ steclebout_nice.pdf

TAYLOR, J. B.: Macroeconomic Policy in a World Economy: from econometric design to practical operation. W.W.Norton \& Company, New York, 1993. ISBN: 0-393-96316-0.

WALSH, C. E: Monetary Theory and Policy. Second Edition. Massachusetts Institute of Technology, 2003. ISBN 0-262-23231-6.

WOODFORD, M.: The Taylor Rule and Optimal Monetary Policy. [online] 2001 [cit. 2006-03-10] $<$ http://www.columbia.edu/ mw2230/taylor.pdf $>$ ŽÍDEK, L.: Transformace. Praha: C. H. Beck, 2006. ISBN: 80-7179-922-X.

Ing. Lubor Lacina, Ph.D., Ing. Svatopluk Kapounek, Ústav financí, Mendelova zemědělská a lesnická univerzita v Brně, Zemědělská 1, 61300 Brno, Česká republika, e-mail: lacina@mendelu.cz, skapounek@mendelu.cz 
